\title{
ISOLATION AND IDENTIFICATION OF ANTIMICROBIAL PROTEINS FROM THE LEAVES OF VALERIANA HARDWICKII AND SENNA OBTUSIFOLIA
}

\author{
MADHURI HARSHA N, PIYUSHIKA DULLOO, RUPACHANDRA S*, JAGADEESHWARI S, JOANN DAVINA M, \\ PORKODIS
}

Department of Biotechnology, School of Bioengineering, Faculty of Engineering and Technology, SRM Institute of Science and Technology, Kattankulathur, Chennai - 603 203, Tamil Nadu, India. Email: rupachandra.s@ktr.srmuniv.ac.in

Received: 10 October 2017, Revised and Accepted: 29 November 2017

ABSTRACT

Objective : The aim of this study was to screen the antimicrobial activity of trypsin-digested peptides isolated from the protein extracts of Valeriana hardwickii and Senna obtusifolia.

Methods: The proteins were extracted from the leaves of $V$. hardwickii and S. obtusifolia which were analyzed using sodium dodecyl sulfatepolyacrylamide gel electrophoresis. The protein extracts were digested using trypsin which was identified using reverse-phase high-performance liquid chromatography analysis. Further, the antimicrobial efficacy of the digested peptides was investigated.

Result: Peptide extracts of $V$. hardwickii exhibited potent antifungal and antibacterial activity at the maximum concentration of 1.5 mg/ml. Similarly, S. obtusifolia exhibited increased antifungal and antibacterial activity at the concentration of $1.44 \mathrm{mg} / \mathrm{ml}$.

Conclusion: The trypsinized extracts of V. hardwickii and S. obtusifolia were plated against Bacillus subtilis which is a promising antibacterial agent.

Keywords: Valeriana hardwickii, Senna obtusifolia, Sodium dodecyl sulfate-polyacrylamide gel electrophoresis, Reverse-phase high-performance liquid chromatography, Antifungal, Antibacterial.

(C) 2018 The Authors. Published by Innovare Academic Sciences Pvt Ltd. This is an open access article under the CC BY license (http://creativecommons. org/licenses/by/4. 0/) DOI: http://dx.doi.org/10.22159/ajpcr.2018.v11i3.23009

\section{INTRODUCTION}

Use of plants as a source of medicine has been an ancient practice and is an essential component of the health-care system in India. Ayurveda form of medicine is considered to be existent in India for thousands of years. It employs various techniques to provide healing or relief to the ailing patients. The medicinal value of plants [1] lies in some chemically active substances that produce a definite physiological action on the human body. The important bioactive constituents of the plants are alkaloids, tannins, flavonoids, and phenolic compounds [2,3]. The evolving commercial importance of secondary metabolites has in recent years resulted in a great interest in secondary metabolism, particularly in the possibility of altering the production of bioactive plant metabolites using tissue culture technology. Many efforts have been made to discover new antimicrobial [4,5] compounds from diverse sources such as soil, microorganisms, animals, and plants. The aim of this study is to isolate and identify the biologically active trypsindigested peptides from Valeriana hardwickii and Senna obtusifolia.

\section{METHODS}

\section{Plant materials and reagents}

Fresh leaves of $V$. hardwickii and S. obtusifolia were collected and authenticated (by Dr. P. Jayaraman, Director of Plant Anatomy Research Centre, Chennai). All buffers and chemicals used were of analytical grade.

\section{Protein extraction}

Leaves of $V$. hardwickii and $S$. obtusifolia were washed with distilled water and shade dried. The dried leaves were ground to fine powder. About $5 \mathrm{~g}$ of powdered leaf sample was extracted with $50 \mathrm{ml}$ of extraction buffer consisting of $10 \mathrm{mM} \mathrm{Na}_{2} \mathrm{HPO}_{4}, 15 \mathrm{mM} \mathrm{NaH} \mathrm{PO}_{4}$, $10 \mathrm{mM} \mathrm{KCl}$, and 2mM EDTA ( $\mathrm{pH} \mathrm{7.0)}$ ) and kept in constant stirring for $3 \mathrm{~h}$ at $4^{\circ} \mathrm{C}$. The contents were filtered and centrifuged at $5000 \times \mathrm{g}$ for $20 \mathrm{~min}$. The crude supernatant was lyophilized and kept for further use. The crude supernatant (lyophilized) was further processed by ammonium sulfate for precipitation of proteins with various saturation limits from 20 to $80 \%$. The concentrations of proteins present in the precipitated samples were estimated by Bradford assay [6].

Sodium dodecyl sulfate-polyacrylamide gel electrophoresis (SDS-PAGE)

SDS-PAGE is a widely used technique to separate proteins depending on their electrophoretic mobility [7,8]. About $20 \mu \mathrm{l}$ of the crude supernatant was loaded into Lanes 2 and 4 of the gel and Lane 1 represents the protein marker of size $66.4 \mathrm{kDa}$. The gel was kept under electrophoretic run for $90 \mathrm{~min}$ at $50 \mathrm{~V}$ and the protein bands were detected. The concentration of the protein test samples was identified using Lowry's method [9].

\section{Enzyme digestion of the crude proteins}

The protein bands were cut from the gel and cut into smaller pieces and placed in a microcentrifuge tube. $200 \mu \mathrm{l}$ of wash solution was added and incubated overnight at room temperature. $200 \mu \mathrm{l}$ of acetonitrile was added and dehydrated at room temperature for $10 \mathrm{~min}$, and the excess acetonitrile was removed from the sample. The gel pieces were dried at ambient temperature in a vacuum centrifuge for 2-3 min. $30 \mu \mathrm{l}$ of $10 \mathrm{Mm}$ DTT was added and the protein was reduced for $30 \mathrm{~min}$ at room temperature. The gel pieces were washed with $200 \mu \mathrm{l}$ of acetonitrile for $5 \mathrm{~min}$. The gel pieces were rehydrated in $200 \mu \mathrm{l}$ of $100 \mathrm{Mm}$ ammonium bicarbonate. The samples were incubated for $10 \mathrm{~min}$ at room temperature and washed with $200 \mu \mathrm{l}$ of acetonitrile for $5 \mathrm{~min}$. $30 \mu \mathrm{l}$ of trypsin was added to the sample, and the gel pieces were allowed to rehydrate in ice for $10 \mathrm{~min}$ with vortex mixing. The gel pieces were centrifuged for $30 \mathrm{~s}$. $5 \mu$ of $50 \mathrm{mM}$ ammonium bicarbonate was added to the sample and mixed. The sample was centrifuged for $30 \mathrm{~s}$ and incubated overnight at $37^{\circ} \mathrm{C} .30 \mu \mathrm{l}$ of $50 \mathrm{Mm}$ ammonium bicarbonate was added to the digest and the sample was incubated for $10 \mathrm{~min}$ with vortex mixing. The digest was centrifuged for $30 \mathrm{~s}$ and the supernatant was collected [10] 
Reverse-phase high-performance liquid chromatography (RP-HPLC) analysis of the peptide extracts

The organic solvent was removed from the RP-HPLC [11,12] column with degassed water using a gradient from $100 \%$ organic solvent to $100 \%$ water over $15 \mathrm{~min}$ at $1 \mathrm{ml} / \mathrm{min}$. Detection settings are 0.1 Absorption Units Full Scale (AUFS) at 210-220 nm for 50-200 per mole peptide. Convenient AUFS settings are 0.3 for 500 per mole, 0.5 for $1 \mathrm{nmol}$, and 1.0 for 2 nmole. The RP peptide standards and the digestion mixture of peptides were centrifuged at $5000 \mathrm{~g}$ for $5 \mathrm{~min}$. An aliquot of the solution was removed from the HPLC syringe and the injection loop was loaded. For digestion mixture of peptides from a protein of interest, the injection volume can be significantly larger. The mixture was injected and the RP-HPLC column was run at $1 \mathrm{ml} / \mathrm{min}$.

\section{Evaluation of antimicrobial activity of peptide extracts}

A volume of $25 \mathrm{ml}$ of LB Agar was poured onto the Petri plates and allowed to solidify. $0.1 \%$ of the culture was swabbed onto the surface of the media and allowed to dry for $5 \mathrm{~min}$. The loaded discs were placed on the surface of medium and the compounds were allowed to diffuse for $5 \mathrm{~min}$ and the plates were kept for incubation at $37^{\circ} \mathrm{C}$ for $24 \mathrm{~h}$. The positive control used was ceftriaxone. Negative control used was trypsin [13,14]. $25 \mathrm{ml}$ of the potato dextrose agar was poured onto the Petri plates and allowed to solidify. $0.1 \%$ of the subculture was swabbed onto the surface of the media and allowed to dry for $5 \mathrm{~min}$. Positive control used was Ketoconazole. The negative control used was trypsin solution [15-17].

\section{RESULTS}

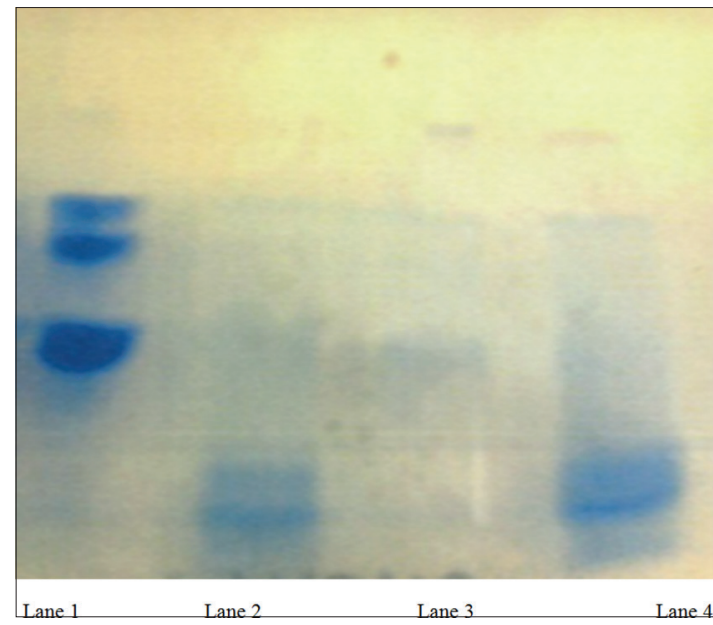

Fig. 1: Sodium dodecyl sulfate-polyacrylamide gel electrophoresis analysis of the peptide extracts of Valeriana hardwickii and Senna obtusifolia. Lane1: Bovine serum albumin (standard protein marker 66.4 KDa), Lane 2: Crude supernatant of V. hardwickii, Lane 4: Crude supernatant of $S$. obtusifolia
The concentration of proteins of $V$. hardwickii and S. obtusifolia was found to be $1.5 \mathrm{mg} / \mathrm{ml}, 1.4 \mathrm{mg} / \mathrm{ml}$, respectively [18]. Molecular weight analyses of the crude supernatant depicted the presence of proteins in the range of 15-20 kDa as showed in Fig. 1, using bovine serum albumin (protein marker) [19].

The peptides of $V$. hardwickii and S. obtusifolia were identified by performing RP-HPLC. The results are showed in Fig. 2A and B.

Antimicrobial assays of peptide extract of $V$. hardwickii and S. obtusifolia depict significant results as shown in Fig. 3 and 4.

\section{DISCUSSION}

Antimicrobial peptides (AMPs) are considered to play important roles in the innate host defense mechanisms of most living organisms. Plants generally produce many secondary metabolites which are an important source of microbicides, pesticides, and various pharmaceutical drugs [20]. The peptide extracted from V. hardwickii and S. obtusifolia was digested using trypsin and the antimicrobial activity was performed. The trypsinized peptides were further analyzed with RP-HPLC [21] and various retention time periods were observed ranging from 1.936 to 27.162 min for $V$. hardwickii and S. obtusifolia. Peptide extracts of $V$. hardwickii exhibited potent antifungal and antibacterial activity [22-30] at the maximum concentration of $1.5 \mathrm{mg} / \mathrm{ml}$. Similarly, $S$. obtusifolia exhibited increased antifungal and antibacterial activity at the concentration of $1.44 \mathrm{mg} / \mathrm{ml}$. Previous studies reported about lunatusin, a peptide with molecular mass of $7 \mathrm{kDa}$ purified from Chinese lima bean (Phaseolus lunatus L.) which exerted antibacterial and antifungal activities. Another peptide, named vulgarinin, from seeds of haricot beans (Phaseolus vulgaris), with a molecular mass of $7 \mathrm{kDa}$ also showed antibacterial activity [31,32].

\section{CONCLUSION}

Peptide extracts of $V$. hardwickii, S. obtusifolia exhibited potent antimicrobial activity depicting remarkable inhibition of the bacterial and fungal growth. Further, the results achieved in this study provide the potential use of AMPs to develop antioxidant, antibacterial, antifungal, and anti-inflammatory agents. Isolation and purification of peptides from V. hardwickii and S. obtusifolia have framed a pathway for the development of peptide-based drug delivery.

\section{AUTHOR CONTRIBUTION}

The first two authors have contributed for laboratory work. Third, fourth and fifth authors other than the corresponding author, have provided the drafting of the manuscript and critical revision

\section{CONFLICT OF INTERESTS}

Declared none

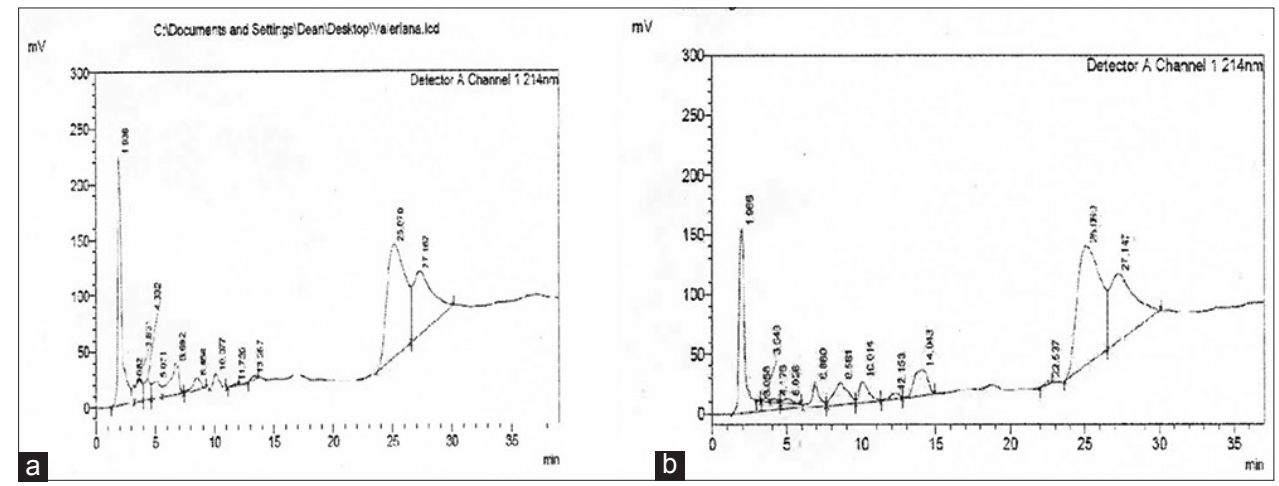

Fig. 2: (a) Reverse-phase high-performance liquid chromatography (RP-HPLC) analysis of the peptide sample of Valeriana hardwickii (b) RP-HPLC analysis of the peptide sample of Senna obtusifolia 


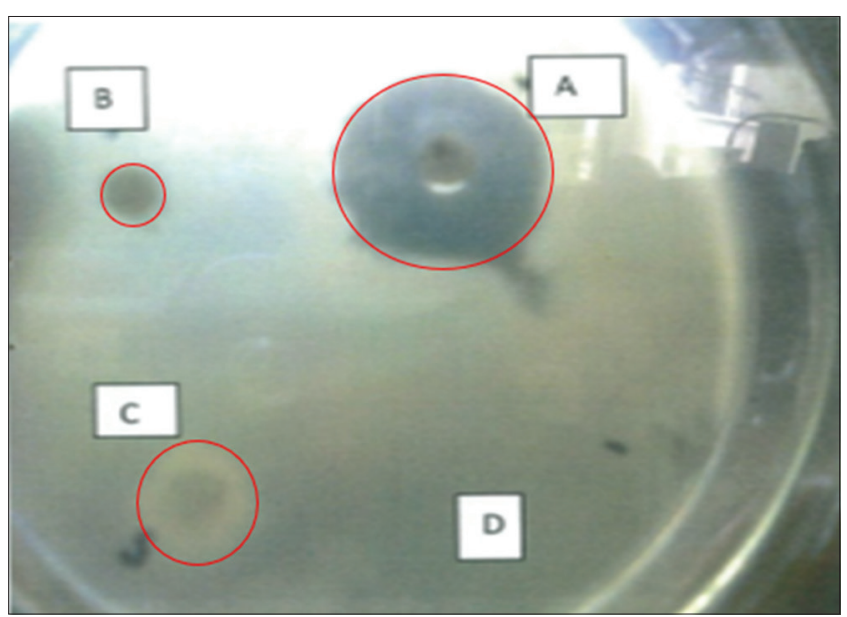

Fig. 3: Antibacterial activity of digested peptides of Valeriana hardwickii and Senna obtusifolia against Bacillus subtilis (A) Positive control (Ceftriaxone), (B) digested peptide sample of V. hardwickii, (C) digested peptide sample of $S$. obtusifolia, (D) negative control (Trypsin)

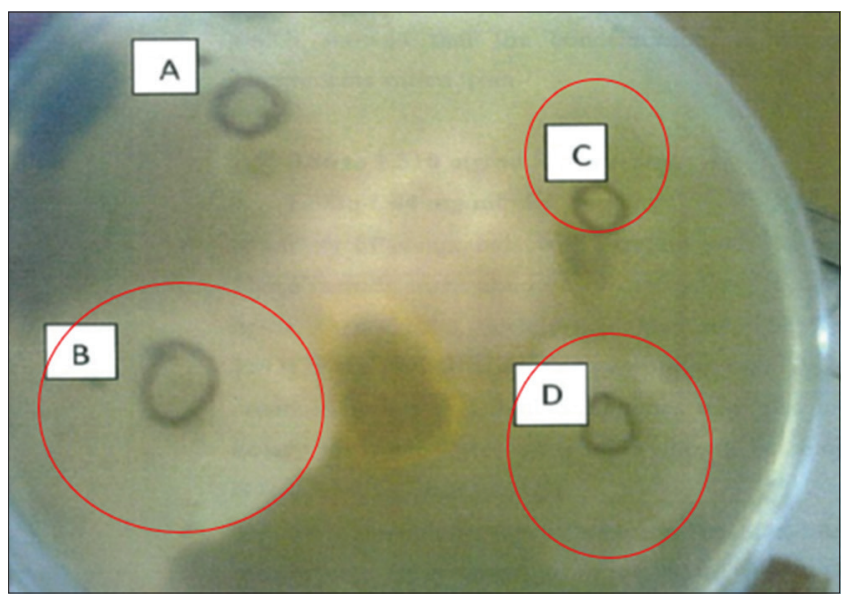

Fig. 4: Antifungal activity of digested peptides of Valeriana hardwickii and Senna obtusifolia against Coriolus versicolor. (A) Negative control (Trypsin), (B) positive control (Ceftriaxone), (C) digested peptide sample of $S$. obtusifolia, (D) digested peptide sample of $V$. hardwickii

\section{REFERENCES}

1. Rojas JJ, Ochoa VJ, Ocampo SA, Muñoz JF. Screening for antimicrobial activity of ten medicinal plants used in Colombian folkloric medicine: A possible alternative in the treatment of non-nosocomial infections. BMC Complement Altern Med 2006;6:2.

2. Balasundram N, Sundram K, Samman S. Phenolic compounds in plants and agri-industrial by-products: Antioxidant activity, occurrence, and potential uses. Food chem 2006;99:191-203.

3. Rauha JP, Remes S, Heinonen M, Hopia A, Kähkönen M, Kujala T, et al. Antimicrobial effects of finnish plant extracts containing flavonoids and other phenolic compounds. Int J Food Microbiol 2000;56:3-12.

4. Dorman HJ, Deans SG. Antimicrobial agents from plants: Antibacterial activity of plant volatile oils. J Appl Microbiol 2000;88:308-16.

5. Ríos JL, Recio MC. Medicinal plants and antimicrobial activity. J Ethnopharmacol 2005;100:80-4.

6. Bradford MM. A rapid and sensitive method for the quantitation of microgram quantities of protein utilizing the principle of protein-dye binding. Anal Biochem 1976;72:248-54.

7. Schägger H. Tricine-sds-page. Nat Protoc 2006;1:16-8

8. Wang W, Vignani R, Scali M, Cresti M. A universal and rapid protocol for protein extraction from recalcitrant plant tissues for proteomic analysis. Electrophoresis 2006;27:2782-6.

9. Macfarlane GT, Gibson GR, Beatty E, Cummings JH. Estimation of short-chain fatty acid production from pro tein by human intestinal bacteria based on branched-chain fatty acid measurements. FEMS Microbio Lett 1992;101:81-8.

10. Mendez E, Moreno A, Colilla F, Pelaez F, Limas GG, Mendez R, et al. Primary structure and inhibition of protein synthesis in eukaryotic cellfree system of a novel thionin, $\gamma$-hordothionin, from barley endosperm. FEBS Lett 1990;194:533-59.

11. Hamidi M, Zarei N. A reversed phase high performance liquid chromatography method for bovine serum albumin assay in pharmaceutical dosage forms and protein/antigen delivery systems. Drug Test Anal 2009;1:214-18.

12. Van Meer JH, Labadie RP. Straight-phase and reversed-phase highperformance liquid chromatographic separation of valepotriate isomers and homologues. J Chromatogr Biomed Appl 1981;205:206-12.

13. Bhalodia NR, Shukla VJ. Antibacterial and Antifungal activities from leaf extracts of Cassia fistula: An ethnomedicinal plant. J Adv Pharm Technol Res 2011;2:104.

14. Solanki R, Nagori BP. Screening of antibacterial activity of hydroalcoholic extract of Cynodon dactylon. Int J Res Ayurveda Pharm 2012;3:827-29.

15. Rachana S. Antifungal activity and screening and HPLC analysis of crude extracts from Tectona grandis, Shilajit, Valeriana wallichi. Institute of bioengineering and biological sciences, Varanasi, India. Electron J Environ Agric Food Chem 2009;8:218-29.

16. Oyedeji O, Oziegbe M, Taiwo FO. Antifungal and Phytochemical analysis of crude extracts from leaves of Ludwigia abyssinica A. Rich and Ludwigia decurrens Walter, Obafemi Awolowo University, Ile-Ife, Nigeria. J Med Plants Res 2011;5:1192-9.

17. Horigome T, Kumar R, Okamoto K. Effects of condensed tannins prepared from leaves of fodder plants on digestive enzymes in vitro and in the intestine of rats. Br J Nutr 1988;2:275-85.

18. Crockett SL, Schaneberg B, Khan IA. Phytochemical profiling of new and old world Hypericum (St. John's Wort) species. Phytochem Anal 2005; $16: 479-85$.

19. Bhunia AK, Johnson MC, Ray B. Direct detection of an antimicrobial peptide of Pediococcus acidilactici in sodium dodecyl sulfatepolyacrylamide gel electrophoresis. J Ind Microbiol Biotechnol 1987;2:319-22.

20. Kim JY, Park SC, Hwang I, Cheong H, Nah JW, Hahm KS, et al. Protease inhibitors from plants with antimicrobial activity. Int J Mol Sci 2009; 10:2860-72.

21. .Proestos C, Chorianopoulos N, Nychas GJ, Komaitis M. RP-HPLC analysis of the phenolic compounds of plant extracts. Investigation of their antioxidant capacity and antimicrobial activity. J Agric Food Chem 2005;53:1190-5.

22. Mhaske DK, Patil DD, Wadhawa GC. Antimicrobial activity of methanolic extract from rhizome and roots of Valeriana wallichii. Int $\mathrm{J}$ Pharm Biomed Res 2011;2:107-11.

23. Harbottle H, Thakur S, Zhao S, White DG. Genetics of antimicrobial resistance. Anim Biotechnol 2006;17:111-24.

24. Vila J, Ruiz J, Gallardo F, Vargas M, Soler L, Figueras MJ, et al. Aeromonas species. and traveler's diarrhea: Clinical features and antimicrobial resistance. Emerg Infect Dis 2003;9:552-4.

25. Doughari JH, El-Mahmood AM, Tyoyina I. Antimicrobial activity of leaf extracts of Senna obtusifolia (L). Afr J Pharm Pharmacol 2008;2:7-13.

26. Madhu KB, Ayuba SB, Raghavendra S, Mallikarjuna RP. Cinnamomum Genus: A review on its biological activities. Int J Pharm Pharm Sci 2017;9:1-11.

27. Yadav M, Yadav A, Kumar S, Sharma D, Yadav JP. Evaluation of in vitro antimicrobial potential of endophytic fungi isolated from Eugenia jambolana Lam. Int J Pharm Pharm Sci 2014;6:208-11.

28. Antony E, Sathiavelu M, Arunachalam S. Synthesis of silver nanoparticles from the medicinal plant Bauhinia acuminata and Biophytum sensitivum-a comparative study of its biological activities with plant extract. Int J Appl Pharm 2017;9:1-8.

29. Tahvilian R, Moradi R, Zhale H, Zangeneh MM, Zangeneh A, Yazdani H, et al. Ethnomedicinal plants: Study on antifungal activity of essential oil of Pistacia khinjuk (Combined with the dominance $\gamma$-Terpinene) against Candida albicans. Int J Curr Pharm Res. 2016;8:1369-73.

30. Hao J, Li Z, Zhang C, Yu W, Tang Z, Li Y, et al. Targeting NF-кB/AP$2 \beta$ signaling to enhance antitumor activity of cisplatin by melatonin in hepatocellular carcinoma cells. Am J Cancer Res. 2017;7(1):13-27.

31. Wong JH, Ng TB. Lunatusin, a trypsin-stable antimicrobial peptide from lima beans (Phaseolus lunatus L.). Peptides 2005;26:2086-92.

32. Jack HW, Tzi BN. Vulgarinin, a broad-spectrum antifungal peptide from haricot beans (Phaseolus vulgaris). Int J Biochem Cell Biol 2005;37:1626-32. 